\title{
Long-Term Results of Balloon Angioplasty for Native Coarctation of the Aorta in the Surgical Specialty Teaching Hospital/Cardiac Center/Hawler
}

\author{
Parween Noori Ahmed*, Nadine Abdulrazzak Mahmood \\ Department of Pediatrics, College of Medicine, Hawler Medical University, Erbil, Iraq \\ Email: ${ }^{\star d r}$ _parween@yahoo.com, nadine_arm@yahoo.com
}

How to cite this paper: Ahmed, P.N. and Mahmood, N.A. (2016) Long-Term Results of Balloon Angioplasty for Native Coarctation of the Aorta in the Surgical Specialty Teaching Hospital/Cardiac Center/Hawler. Open Journal of Pediatrics, 6, 219-231.

http://dx.doi.org/10.4236/ojped.2016.63031

Received: May 14, 2016

Accepted: August 23, 2016

Published: August 26, 2016

Copyright $\odot 2016$ by authors and Scientific Research Publishing Inc. This work is licensed under the Creative Commons Attribution International License (CC BY 4.0).

http://creativecommons.org/licenses/by/4.0/

\section{(c) (i) Open Access}

\section{Abstract}

Background: Coarctation of aorta is a common congenital cardiac malformation; controversy has surrounded the use of balloon angioplasty for native coarctation of aorta as the primary treatment for patients with various ages with coarctation. Aim: This study aimed to assess the long term outcome of balloon angioplasty especially concerning aneurysm formation. Patients and Methods: A case series (case followup) study was carried out on a total of 50 patients (31 male and 19 female) with native coarctation of aorta aged 1 - 21 years of age who were treated with balloon angioplasty for more than 1 year at the time of follow up evaluation in surgical specialty hospital/cardiac center in Erbil Iraq. They were recalled and subjected to detail clinical examination, body weight, height, blood pressure measurements. Radiographic, Echo Doppler data, CT angiography were obtained. CT angiography was done for 34 patients. Full echocardiographic evaluation was done in follow up visits. Results: There was a significant reduction in the peak instantaneous pressure gradient across the coarctated area by Doppler echocardiogram gradient before balloon angioplasty and at the follow up visit from $56.92 \pm 14.6 \mathrm{mmHg}$ to $30.68 \pm 16.89, \mathrm{P}=0.00$. Six cases of total 50 patients had evidence of diastolic runoff pattern by Doppler Echcardiogram. While the only 6 of total 34 cases had the report of CT angiography that documented aneurysm formation (12\%). Conclusions: Balloon angioplasty of native aortic coarctation can be performed safely and effectively with good immediate outcome. Furthermore, it offers satisfactory long-term results with low incidence of persisting restenosis, hypertension and aneurysm formation.

\section{Keywords}

Coarcation of Aorta, Balloon Angioplasty 


\section{Introduction}

Coarcation of Aorta (COA) occurs in $8 \%$ to $10 \%$ of all cases of congenital heart defect. It is more common in male than female (male/female ratio of 2:1). Among patients with Turners syndrome, $30 \%$ have COA with a higher incidence in stillbirth infants [1]-[4].

Constrictions of the aorta of varying degrees may occur at any point from the transverse arch to the iliac bifurcation [1]. The common form of COA of aorta is represented by a localized constriction containing the ridge or shelf, more common than tubular hypoplasia [5]. The abdominal aorta is rarely involved [4]. COA of the abdominal aorta can be part of a systemic vascular disorder such as Takayasu arteritis or von Recklinghausen disease but also can be congenital [6].

COA occurs as of other congenital heart defects such as bicuspid aortic valve (as many as $85 \%$ of patients with COA have bicuspid aortic valve), transposition of great arteries, double outlet right ventricle (taussing being anomaly), discordant ventriculoarterial connection, common arterial trunk, ventricular septal defect (defects are more frequently perimembranous and associated with postero-inferior overriding of the aortic valve), interruption of the aortic arch which can be found with an aortopulmonary window rather than VSD, and mitral valve abnormalities (a supravalvular mitral ring or parachute mitral valve, and subaortic stenosis are potential associated lesion, when this group of left-sided obstructive lesions occurs together, they are referred to as the shone complex) [1]-[3] [7]. Bicuspid aortic valve disease is a big contributor to cardiac failure, which in turn makes up roughly $20 \%$ of late deaths to coarctation patients [7]. The diagnosis of COA in older children and adult usually follows a routine medical examination, where the murmur is discovered; weak femoral pulse, or unexplained systemic hypertension is found; headache, nosebleeds, cold feet or calf pain on exercise is often experienced. The major complications of COA are congestive heart failure, subarachnoid hemorrhage, infective endocarditis and aortic dissection; dissection is particularly dangerous in pregnant women [5] [8].

The pathogensis of systemic hypertension in COA of aorta has been the subject to the theory that the mechanics focuses on resistance at the site of obstruction. This theory in itself cannot be sustained, but it is central to the neural theory that involves the distensibility characteristics of the pre COA aorta, the sensitivity of carotid sinus baroreceptors and relatively non compliant precoarctation aorta [9] [10]. Also elastic properties of the normal aorta decrease with distance from the aortic root. In COA of aorta, the proximal aortic segment is characterized by an increase in collagen and a decrease in smooth muscle [11].

There are two pathognomonic signs on the plain CXR in older children. The first is figure- 3 sign. The upper arc of the 3 is the dilated arch proximal to the COA and/or a dilated left subclavian artery. The lower arc or bulge represents post stenotic dilatation of the aorta immediately below the COA. The indentation between the 2 bulges is the COA itself. When the esophagus is filled with barium, a reverse 3 or $E$ sign is often seen; it is a mirror image of the areas of prestenotic and poststenotic dilatation [1] [12]. 
The second sign is rib notching, which is usually not seen until 4 years of age. It is best seen posteriorly in the medial third of the lower borders of the fourth to eight ribs, where the intercostals artery cross the rib notching is present in $75 \%$ of adults with COA. It is caused by pulsation of dilated intercostals arteries [1] [13] [14]. MRI vividly portrays the anatomy of the COA. It also demonstrates the bicuspid valve and the state of left ventricular function, as well as restenosis following angioplasty or surgical repair. The degree of confidence is very high [1] [15]-[18].

Echocardiography: There is most commonly a short narrowed segment just distal to the left subclavian artery caused by the obstructive shelf projecting into the aorta posteriorly. More rarely there is a longer segment of narrowing involving the isthmus [1] [2] [19]-[21]. Doppler examination often demonstrates a pattern of diastolic runoff, especially in patients with robust collaterals or tight stenosis [2]. However, in the presence of a patent ductus arteriosus, the severity of the narrowing may be underestimated [22].

Cardiac Catheterization and Angiography: one potential indication is for intervenesion in the setting of COA. Controversy has surrounded the use of balloon angioplasty as the primary treatment for patients with various ages. The first operations to treat COA were carried out by Clarence Crafoord in Sweden in 1944 [1] [23] [24].

Angioplasty is a procedure done to dilate an abnormally narrow section of a blood vessel to allow better blood flow, After a COA repair $20 \%-60 \%$ of infant patients may experience reoccurring stenosis at the site of the original operation [25]. Immediate and intermediate-term follow up are generally good with a small chance for recoarctation and aneurismal formation at the site of COA. The causes of recoarctation were identified and include age less than 1 year, isthmus hypoplasia, and a small coarcted aortic segment. [26] [27] and long-term follow up studies are required prior to recommending angioplasty as an alternative to surgical therapy in adult patients [28].

American Heart Association released in 2011. Angioplasty for native COA is a Class IIa indication as a palliative measure to stabilize a patient with severely depressed ventricle function. In addition, Class IIb indications include patients beyond four to six months of age with suitable anatomy (discrete COA). Regarding stenting, Class IIa indications include use of stents that can be dilated to adult size diameters in native (discrete or long segment) COA when angioplasty has failed [29].

A number of potential factors may be responsible for the development of aneurysms after percutaneous balloon angioplasty, Previous histologic studies demonstrated extensive intimal and medial tears in resected COA segments that were dilated. Cystic medionecrosis, by contributing to the progression of intimal and medial tears, could lead to the adverse effects now being reported after balloon angioplasty [30].

Another probable mechanism of aneurysm formation after angioplasty is over distension may cause complete a complete trans medial tear resulting in loss and disarray of supporting smooth muscle cells causing weakening in the vessel wall, Anurysm following dilation occur in $2 \%-5 \%$ of patients and appears related to degree of anatomical enlargement [31]. 


\section{Patients and Methods}

Study design: case series (case follow up study).

Between March 2008 and February 2015, percutaneous balloon angioplasty was attempted in 110 patients with native COA of aorta for duration of more than one year in both gender between age 1 - 21 years of age who had been admitted to surgical specialty hospital/cardiac center which the only center in Erbil which deals with cardiac problems. A total of 50 patients were included in our study, 31 (62\%) male and 19 (38\%) female, the remaining other 60 cases were lost for follow up because they did not keep any contact with hospital.

Patients who underwent stent implantation or surgery for repair of COA, those with balloon angioplasty for less than 1 year and those with age more than 21 years, are excluded from the study. Data for 50 patients by recall them, were obtained by direct interview and examination of the patients asking for their consent for full ethical consideration, and from hospital based medical records. Case notes of all patients meeting including clinical examination, body weight, height, Blood pressure measurements, radiographic, Echo Doppler data, CT angiography were obtained, the mean duration of follow up visit for long term complications after the procedure was $3.02 \pm 1.59$ years. Measure blood pressure in the supine position with standard sphygmomanometric auscultatory method without discontinuation of antihypertensive medication. Measured Systolic and diastolic blood pressure were plotted on auscultatory BP percentiles curves according to age for boys and girls. Echo-Doppler examinations (VIVID 3 generation machine) were performed on follow up visit. A two, three or five $\mathrm{MHz}$ probe was used for examination. The maximum peak instantaneous gradient across the previously dilated coarctated area was determined by using a standard Doppler approach and calculated using the modified Bernoulli equation [2]. The spectral recording shows an extension of antegrade flow, and persisting gradient into diastole, so called diastolic tail. The spectral recording can be analyzed further according to peak velocity and the half-time of diastolic velocity decay. This predicts accurately severity of anatomical obstruction [1]. Full catheterization data were reviewed including the systolic, and mean pressure gradient of ascending and descending aorta (peak-to-peak systolic gradient) before and after balloon angioplasty.

Statistical analysis: Data were analyzed using the Statistical Package for Social Science (SPSS version 19). Mean and standard deviation used for numerical data, Paired $\mathrm{T}$ test was used to compare mean between readings before and after the procedure, $P$ value of $\leq 0.05$ was considered as statistically significant.

Limitation of the Study: one of the limitation of the study that we did a several trails to contact with cases, but they did not response to us, may be because of they are far away from the center or economic factors and security factors because of many patients leave in the middle and south Iraq which is difficult to come to north of Iraq (our situation) another limitation was many of patients refuse to do CT angiography [31].

Results: The current study included 50 patients with congenital native COA in whom balloon angioplasty done for more than 1 year duration at the time of follow up 
visit to evaluate the complication of balloon angioplasty of both gender between the age of 1 - 21 years old CT angiography done for 34 patients for the evaluation of the complication of balloon angioplasty at the follow up visit, the remaining 16 cases of them refuse the CT angiography, The clinical and demographic characteristics of the studied patients at the time of follow up visit are illustrated in (Table 1), the mean age of patients was $10.37 \pm 6.42$ years (range 1.3 - 21 years), with a male predominance: male/ female $=31(62.0 \% / 19(38 \%)$, mean duration of follow up evaluation visit after balloon angioplasty was $(3.02 \pm 1.59)$ years, range between ( $1-6.5$ years) (Table 1$)$.

Systolic blood pressure measurements in the supine position with standard sphygmomanometric auscultatory method without discontinuation of antihypertensive medications and data plotted on chart of both gender of Normative BP percentile values. Systolic and diastolic BP mean and Standard deviation are (114.46 \pm 23.85$)$, (59.54 \pm 17.36) respectively. Chart 1 and Chart 2 show number and percentage of measured systolic and diastolic BP percentile respectively.

Table 1. The clinical characteristics of patients with COA after Balloon angioplasty.

\begin{tabular}{cc}
\hline Variables & Patients $(\mathrm{n}=50)($ mean \pm SD or \%) \\
\hline Age (years) & $10 \pm 6$ \\
Gender & Male $31(62 \%)$ \\
Body weight $(\mathrm{kg})$ & Female $19(38 \%)$ \\
Height & $33.28 \pm 22.06$ \\
Systolic BP & $124.8 \pm 31.79$ \\
Diastolic BP & $114.46 \pm 23.85$ \\
Age of procedure & $59.54 \pm 17.36$ \\
Duration of follow up evaluation & $3.02 \pm 1.59$ \\
\hline
\end{tabular}

$\mathrm{N}=$ patient number; $\mathrm{SD}=$ standard duration.

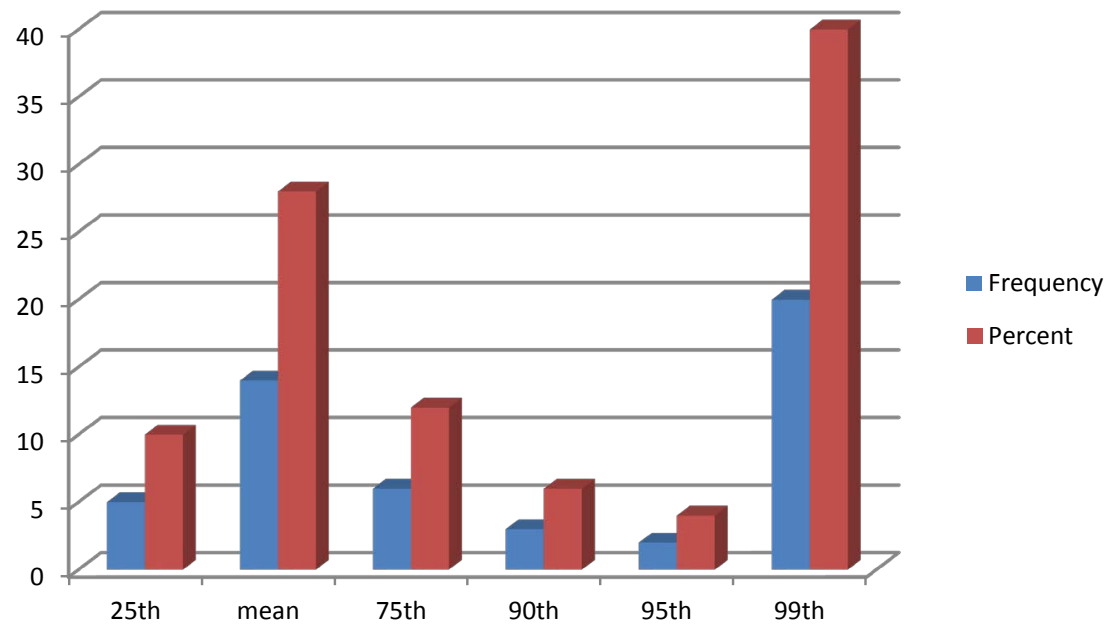

Chart 1. Frequency and percentage of measured systolic BP. 
Antihypertensive agents in form of diurectis (fursemide, aldactone), ACI inhibitor (Enalpril, captopril), adrenergic inhibitors (Propranolol, Atenolol, Metoprolol...), it was found that 17 (34\%) of patient were on antihypertensive agents while 33 (66\%) on no treatments, Chart 3 shows the number and percentage of patients that on antihypertensive agents and Table 2 shows type of antihypertensive agent.

It has been found that 27 (54\%) of Patients had normal CXR, 12 (24\%) had cardiomegaly, Rib notching is found in $10(2 \%)$, Notching of the ribs is a classic radiologic signs of COA of the aorta caused by collateral flow through dilated, tortuous, pulsatile posterior intercostals arteries (Tables 3-5) [32].

The associated cardiac anomaly is found among 24 (48\%) of patients with COA of aorta inform of subaortic ridge, PDA, AS, MS, mitral valve prolapse...

Turner syndrome is found among 3 patients.

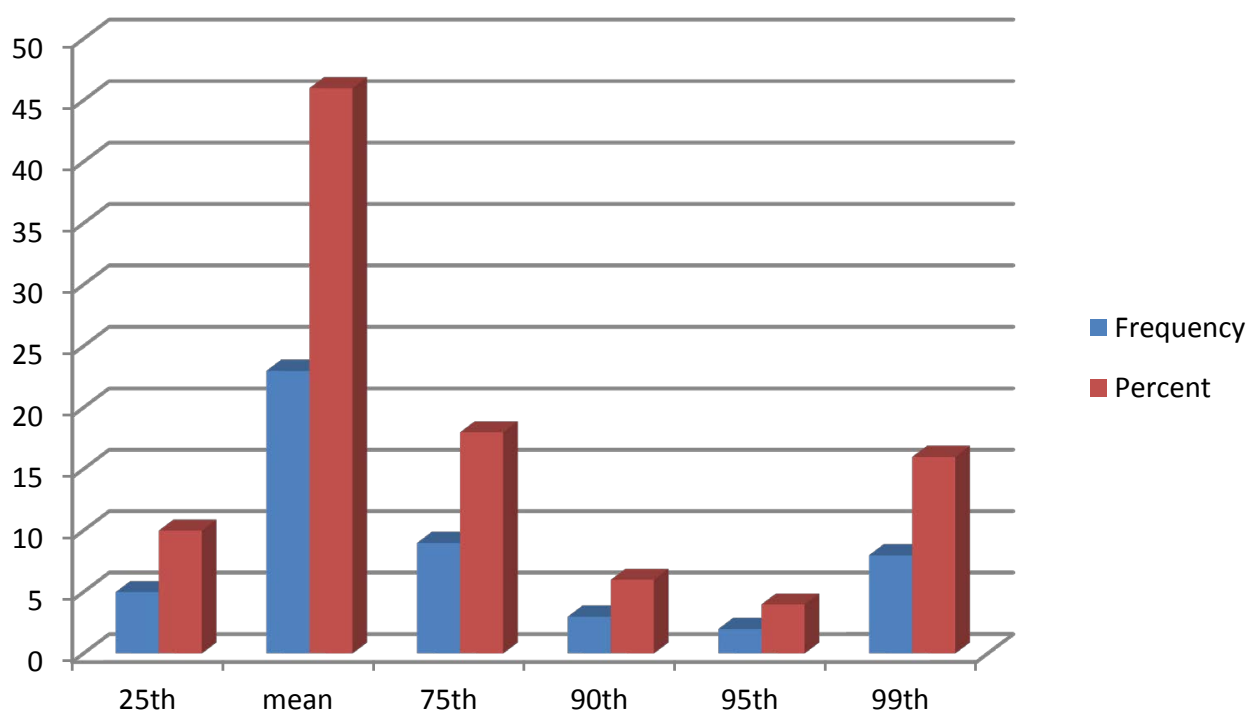

Chart 2. Frequency and percentage of measured diastolic BP.

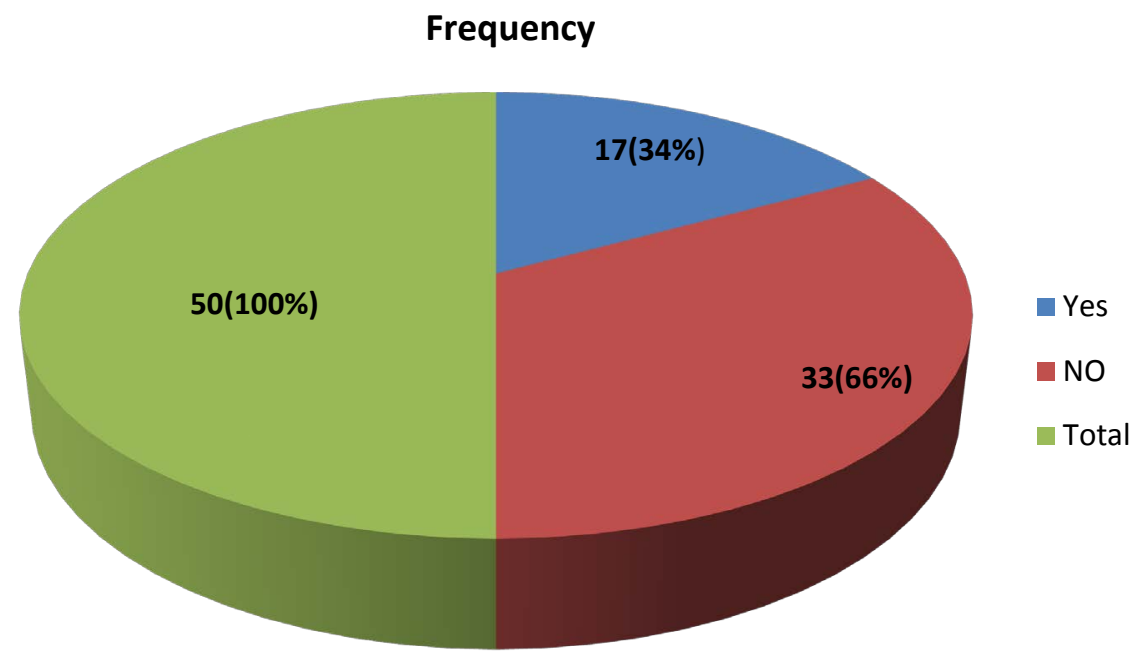

Chart 3. Frequency and percentage of patients with and without antihypertensive agents. 
Table 2. Frequency of the patients who are on antihypertensive agents.

\begin{tabular}{cc}
\hline Type of antihypetensive agents & Frequency and percentage \\
\hline ACI & $9(18 \%)$ \\
Adrenergic inhibiter & $2(4 \%)$ \\
ACI + adrenergic inhibitor & $1(2 \%)$ \\
ACI and diurectis & $5(10 \%)$ \\
\hline
\end{tabular}

ACI: Angiotensine converting enzyme inhibitor.

Table 3. CXR finding in patients of coarcation of aorta.

\begin{tabular}{ccc}
\hline CXR & Frequency & Percent \\
\hline Normal & 27 & $54 \%$ \\
Cardiomegally & 12 & 24 \\
Dialtion of ascending aorta & 1 & $2 \%$ \\
Rib notching & 10 & $20 \%$ \\
Total & 50 & 100.0 \\
\hline
\end{tabular}

CXR: chest X ray.

Table 4. No. and type of associated anomaly.

\begin{tabular}{ccc}
\hline No. and type of associated anomaly & Frequency & Percent \\
\hline Subaortic ridge & 2 & $4 \%$ \\
PDA & 5 & $10 \%$ \\
AS & 5 & $10 \%$ \\
AI & 4 & $8 \%$ \\
RPA stenosis & 1 & $2 \%$ \\
Mitral valve prolapse & 2 & $4 \%$ \\
VSD + MS & 1 & $2 \%$ \\
MS & 1 & $2 \%$ \\
PDA + AI & 2 & $4 \%$ \\
MS + PDA & 1 & $2 \%$ \\
Total & 24 & $48 \%$ \\
\hline
\end{tabular}

NO: number, PDA: patent ductus arteriosus, AI: aortic incompetence, AS: aortic stenosis, RPA: Rt pulmonary artery stenosis, MS: mitral stenosis, VSD: ventricular septal defect.

Table 5. Peak instantaneous pressure gradient before and after balloon by Doppler echocardiogram.

\begin{tabular}{ccc}
\hline $\begin{array}{c}\text { Peak instantaneous pressure gradient } \\
\text { before balloon angioplasty (mean } \pm \text { SD) }\end{array}$ & $\begin{array}{c}\text { Peak instantaneous pressure gradient after balloon } \\
\text { angioplasty at follow up visit (mean } \pm \text { SD) }\end{array}$ & P value \\
\hline $56.92 \pm 14.16$ & $30.68 \pm 16.89$ & 0.00 \\
\hline
\end{tabular}

SD: standard deviation. 
At the follow up visit, it was found that there is significant reduction in the pressure gradient across the coarctated area by Doppler echocardiogram gradient before balloon angioplasty and at the follow up visit from $56.92 \pm 15.2 \mathrm{mmHg}$ to $30.6 \pm 16.89, \mathrm{P}=0.00$.

Paired $\mathrm{T}$ test is used to compare mean of peak instantaneous pressure gradient of sample before COA balloon angioplasty and after it, it founded that calculated t test is 9.72 and the tabulated $t$ test (with level of significance is 0.05 ) is 2.05 so we reject the null hypothesis and we conclude that there is significant difference between the mean of peak instantaneous pressure gradient before and after COA balloon angioplasty.

It was found that one case of which his age between $1-4$ years with diastolic runoff and significant pressure gradient across the coarctated area by Doppler Echocardiogram referred to surgery, meanwhile three cases of which their aged 5 - 9 years had pattern of diastolic runoff, stent had been put for two of them and the other one referred to surgery, also stent had been put for the one in whom aged 10 - 14 years, the one who older than 15 years missed for the follow up (Table 6).

While the only 6 of total 34 cases who had CT angiography (12\%) had the report of $\mathrm{CT}$ angiography that documented aneurysm. An aneurysm was defined as an aortic ratio of greater than 1.5, measuring aortic diameter at the coarctated repair site and the thoracic aorta at the level of diaphragm [33].

\section{Discussion}

In the present study, we demonstrate a satisfactory long term reduction in the peak instantaneous pressure gradient by Doppler echocardiography from $56.92 \pm 14.16$ to $30.68 \pm 16.89$, (P value $=0.00$ ), While $12 \%$ ( 6 of total 34 cases $)$ reported aneurysm formation after follow up evaluation of mean duration ( $3.02 \pm 1.59$ years).

A study done in USA who studied 20 patients, which found a decrease in calculated instantaneous COA pressure gradient across COA From mean $(43.3 \pm 21.9 \mathrm{mmHg})$ to (to $25.3 \pm 10.6 \mathrm{mmHg}$ ) for mean duration of follow up of 12 months, $(\mathrm{P}<0.01)$ which is nearly comparable with the our study [33]. The same study reported no aneurysm formation [27]. While $12 \%$ in our study, restenosis occur more often with young age and a hypoplastic transverse arch [31].

Another study which done in Riyadh Saudi Arabia, concluded that the doppler COA gradient across the COA site decreased from $57.6 \pm 17.7 \mathrm{mmHg}$ to $16.6 \pm 8.4 \mathrm{mmHg}$

Table 6. Pattern of diastolic runoff according to the age groups.

\begin{tabular}{ccccc}
\hline & & \multicolumn{2}{c}{ Pattern of diastolic runoff } & Total \\
\cline { 3 - 4 } & & Yes & No & 13 \\
\hline \multirow{2}{*}{ Age groups } & $1-4$ & 1 & 12 & 13 \\
& $5-9$ & 3 & 10 & 8 \\
& $10-14$ & 1 & 7 & 16 \\
& More 15 and & 1 & 44 & 50 \\
\hline
\end{tabular}


one year after angioplasty [34].

While one done by a group of researchers who studied 26 patients, founded that mean peak systolic blood pressure was $(111.1 \pm 14.1 \mathrm{mmHg})$ at long-term follow-up ( $\mathrm{P}$ $<0.05)$, which is consistent with our study [35]. In Saudi Arabia found that the measured systolic blood pressure values were $(134 \pm 18 \mathrm{mmHg})$, which is incomparable with our study in which measured systolic blood pressure was (114.46 \pm 23.85$)$ [36].

Another study founded that reduction in systolic blood pressure ranged from $167 \pm$ 28 to $132 \pm 17 \mathrm{mmHg}$ at the long term follow. While did not demonstrate aneurysm formation in their series [33].

A prospective case series study done by Munayer Calderon, who studied 333 cases of native COA, reported only 15 people developed aneurysm [37]. While a randomized controlled trial done by Shaddy, in USA done on 36 cases with native COA, age range between 3 to 10 years who founded that 4 case developed aneurysm [38].

A study done by a group of researchers, founded that three patients from total of 7 cases (43\%) reported aneurysm formation [39].

Another study done in Texas concluded that small aneurysm was found in 2 (1.9\%) of 102 patients [40]. In large series of patients 140 patients, they found that 2 early and 6 late aneurysms reported after the COA dilation, which is inconsistent with our study [41].

Some aneurysms developed late, first being detected more than 5 years after the initial intervention. Only $50 \%$ of balloon angioplasty subjects remained free of both aneurysm formation and repeat intervention [26].

Another researcher who studied 20 children aged 6 - 30 months following dilatation of native COA and 4 children, aged 6 - 22 months following dilatation of recoarctation and none developed aneurysms [42]. The reason for this difference is not clear. It was founded that use of large balloons, inadvertent manipulation of catheter/guide wires in the region of freshly dilated aortic COA, and misinterpretation or over interpretation of aneurysm as possible causes [43].

In study that done in Texas documented that $88 \%$ of patients who had a successful angioplasty maintained a gradient of $<20 \mathrm{mmHg}$ over a mean period of 33.8 months follow up [40].

By follow up angiogram at 12 months and serial MRI up to 10 years after initial dilation were scrutinized for aneurysm formation at the site of balloon angioplasty, three from total of 43 patients were observed to had aneurysm by both an angioplasty and MRI giving the incidence of $7 \%$ [44].

\section{Conclusion}

Balloon angioplasty of native aortic COA can be performed safely and effectively in most infants, children and adolescents with good immediate and short term outcome. Furthermore, it offers satisfactory long-term results with low incidence of persisting hypertension, recoarctation and aneurysm formation. As long as superior long-term follow-up results of aortic stenting are to be awaited, it thus may be considered as first- 
line therapy in adolescents and adults with native and discrete COA. Anurysm formation was an unusual complication. Balloon angiography may be considered as the first line therapy in most children with COA.

\section{Recommendation}

Further long term studies should be undertaken which involve a larger numbers of patients to evaluate results of balloon angioplasty for native COA, and perform angiography to measure peak systolic gradient across the coarctated area more accurately and to know the proportion of cases with recoarctation, Similar to alternatives for angioplasty, life-time surveillance using contemporary imaging techniques is warranted to detect poor outcome in time.

\section{Compliance with Ethical Standards}

I declare that I have no conflict of interest.

Informed consent was obtained from all individual participants included in the study.

\section{References}

[1] Hoschtitzky, A., Anderson, R.H. and Elliott, M.J. (2010) Aortic Coarctation and Interrupted Aortic Arch. In: Anderson, R.H., Baker, E.J., Penny, D.J., Redington, A.N., Rigby, A.N. and Wernovsky, G., Eds., Paediatric Cardiology, 3rd Edition, Churchill Livingstone, Philadelphia, 945-967. http://dx.doi.org/10.1016/b978-0-7020-3064-2.00049-7

[2] Park, M.K. (2008) Pediatric Cardiology for Practitioners. 5th Edition, Mosby Elsevier, Philadelphia, 257-269.

[3] Bernstein, D. (2004) Evaluation of Cardiovascular System. In: Jenson, B.K., Ed., Nelson Textbook of Pediatrics, 17th Edition, Vol. II, Philadelphia Pennsylavia, 1518-1520.

[4] Hay, J.W., Levin, M.J., Sondheimer, J.M. and Deterding, R.R. (2011) Current Diagnosis and Treatment. 20th Edition, USA, 556-557.

[5] Parthasarathy, A., Menon, P.S.N., Nair, M.K.C. and Bhave, S.Y. (2007) Partha's Fundamentals of Pediatrics. Jaypee Brothers, New Delhi, 244.

[6] Robert, H.B., Albert, P.R., Douglas, M.B., Edward, L.B., Crowley, D.M., Dennis, C., Snide, A.R. and Amnon, R. (1986) Long-Term Outcome after Repair of Coarctation in Infancy: Subclavian Angioplasty Does Not Reduce the Need for Reoperation. Journal of the American College of Cardiology, 8, 1406-1411. http://dx.doi.org/10.1016/S0735-1097(86)80314-X

[7] Greenberg, S.B., Marks, L.A. and Eshaghpour, E.E. (1997) Evaluation of Magnetic Resonance Imaging in Coarctation of the Aorta: The Importance of Multiple Imaging Planes. Pediatric Cardiology, 18, 345-349. http://dx.doi.org/10.1007/s002469900196

[8] Feltes, T.F., Bacha, E., Beekman, R., et al. (2011) Indications for Cardiac Catheterization and Intervention in Pediatric Cardiac Disease: A Scientific Statement from the American Heart Association. Circulation, 123, 2607-2652.

http://dx.doi.org/10.1161/CIR.0b013e31821b1f10

[9] Bell, D.R. and Bohr, D.F. (1991) Endothelium in Functional Aortic Changes of Coarctation Hypertension. American Journal of Physiology, 260, H1187.

[10] Walhaut, R.J., Suttorp, M.J., Mackait, G.T., Ernst, J.M., Plokker, H.W., et al. (2009) Long 
Term Outcome after Balloon Angioplasty of Coarctation of the Aorta: Is Aneurysm Formation an Issue? Catheterization and Cardiovascular Interventions, 73, 549-556. http://dx.doi.org/10.1002/ccd.21842

[11] Cumming, G.R. and Mir, G.H. (1970) Exercise Haemodynamics of Coarctation of Aorta. British Heart Journal, 32, 365. http://dx.doi.org/10.1136/hrt.32.3.365

[12] Perloff, J. (2009) The Clinical Recognition of Congenital Heart Disease. 5th Edition, Sunders Elsevier, Philadelphia, 113-143.

[13] William, E.B. and Clyde, H.A. (2012) Coarctation of the Aorta. Fundamentals of Diagnostic Radiology. Lippincott Williams \& Wilkins, 1172.

[14] Giuffre, M., Ryerson, L., Chapple, D., Crawford, S., Harder, J. and Leung, A.K.C. (2005) Nonductal Dependent Coarctation: A 20-Year Study of Morbidity and Mortality Comparing Early-to-Latesurgical Repair. Journal of the National Medical Association, 97, 352-356.

[15] Latrabe, V. (2001) MRI of Aortic Coarctation: Impact in Daily Practice. Journal of Radiology, 82, 539.

[16] Juan, L.J., Krieger, E.V., Valente, A.M., Geva, T., Wintersperger, B.J., Moshonov, H., et al. (2013) Cardiovascular Magnetic Resonance Imaging Predictors of Pregnancy Outcomes in Women with Coarctation of the Aorta. European Heart Journal-Cardiovascular Imaging, jet161.

[17] Nordmeyer, J., Gaudin, R., Tann, O.R., Lurz, P.C., Bonhoeffer, P., Taylor, A.M., Muthurangu, V., et al. (2010) MRI May Be Sufficient for Noninvasive Assessment of Great Vessel Stents: An in Vitro Comparison of MRI, CT, and Conventional Angiography. American Journal of Roentgenology, 195, 865-871. http://dx.doi.org/10.2214/AJR.09.4166

[18] Hornberger, W.F., Weintraub, R.G., Pesonen, E., et al. (1992) Echocardiography Study of the Morphology and Growth of the Aortic Arch in the Human Fetus. Observation Related to the Prenatal Diagnosis of Coarctation. Circulation, 87, 741-747. http://dx.doi.org/10.1161/01.CIR.86.3.741

[19] Singh, N.V. and Lin, C.E. (2013). http://emedicine.medscape.com/article/416623-overview

[20] Lai, W.W., Geva, T., Shirali, G.S., Frommelt, P.C., Humes, R.A., Brook, M.M., Pignatelli, R.H., Rychik, J., et al. (2006) Guidelines and Standards for Performance of a Pediatric Echocardiogram: A Report from the Task Force of the Pediatric Council of the American Society of Echocardiography. Journal of the American Society of Echocardiography, 19, 1413-1430. http://dx.doi.org/10.1016/j.echo.2006.09.001

[21] Bergamini, T.M., Bernard, J.D., Mavroudis, C., Backer, C.L., Muster, A.J. and Richardson, J.D. (1995) Coarctation of Abdominal Aorta. Annals of Vascular Surgery, 9, 352-356. http://dx.doi.org/10.1007/BF02139406

[22] Warnes, C.A., Liberthson, R., Danielson, G.K., Dore, A., Harris, L., Hoffman, J.I.E., Somerville, J., Williams, R.G., Webb, G.D., et al. (2001) Task Force 1: The Changing Profile of Congenital Heart Disease in Adult Life. Journal of the American College of Cardiology, 37, 1170-1175. http://dx.doi.org/10.1016/S0735-1097(01)01272-4

[23] Radegran, K. (2003) The Early History of Cardiac Surgery in Stockholm. Journal of Cardiac Surgery, 18, 564-572. http://dx.doi.org/10.1046/j.0886-0440.2003.02071.x

[24] Fawzy, M.E., Sivanandam, V., Galal, O., Dunn, B., Patel, A., Rifai, A., et al. (1997) One- to Ten-Year Follow-Up Results of Balloon Angioplasty of Native Coarctation of the Aorta in Adolescents and Adults. Journal of the American College of Cardiology, 30, 898-904. http://dx.doi.org/10.1016/S0735-1097(97)00350-1

[25] Cowley, C.G., Orsmond, G.S., Feola, P., McQuillan, L. and Shaddy, R.E. (2005) Long Term, Randomized Comparison of Balloon Angioplasty and Surgery for Native Coarctation of 
Aorta in Childhood. Circulation, 111, 3453-3456.

http://dx.doi.org/10.1161/CIRCULATIONAHA.104.510198

[26] Peuster, M., Wohlsein, P., Brugman, M., et al. (2001) A Novel Approach to Temporary Stenting: Degradable Cardiovascular Stents Produced from Corrodible Metal-Results 6 18 Months after Implantation into New Zealand White Rabbits. Heart, 86, 563-569. http://dx.doi.org/10.1136/heart.86.5.563

[27] Rad, P.S. (1989) Balloon Angioplasty of Aortic Coarctation: A Review. Clinical Cardiology, 12, 618-628. http://dx.doi.org/10.1002/clc.4960121103

[28] Attia, I.M. and Lababidi, Z.A. (1988) Early Results of Balloon Angiography of Native Aortic Coarctations in Young Adults. The American Journal of Cardiology, 61, 930-931. http://dx.doi.org/10.1016/0002-9149(88)90379-7

[29] Singh, V.N., Lin, C.E., Gross, G.W. and Steiner, R.M. (1991) Radiographic Manifestations of Congenital Heart Disease in the Adult Patient. Radiologic Clinics of North America, 29, 293-317.

[30] Isner, J.M., Donaldson, R.F. and Bhan, I. (1986) Cystic Medionecrosis in Coarctation of the Aorta: A Potential Factor Contributing to Adverse Consequences Observed Following Percutaneous Balloon Angioplasty of Coarctation Sites. Journal of the American College of Cardiology, 7, 46A.

[31] Moore, P. and Lock, J.E. (2000) Catheter Intervention: Balloon Angioplasty: Experimental Study, Technology and Methodology. In: Lock, J.E., Keane, J.F. and Perry, S.B., Eds., Diagnostic and Interventional Catheterization in Congenital Heart Disease, 2nd Edition, Kluwer Academic Publisher, Boston, 120-149. http://dx.doi.org/10.1007/978-1-4757-3173-6_5

[32] Jinping, X., Shiota, T., Omoto, R., et al. (1997) Intravascular Ultrasound Assessment of Regional Aortic Wall Stiffness, Distensibility and Compliance in Patients with Coarctation of Aorta. American Heart Journal, 134, 93-98.

[33] Cooper, R.S., Ritter, S.B., Rothe, W.B., et al. (1987) Angioplasty for Coarctation of the Aorta: Long-Term Results. Circulation, 75, 600-604. http://dx.doi.org/10.1161/01.CIR.75.3.600

[34] Fawzy, M.E., Awad, M., Hasan, W., Al-Kadhi, Y., Shoukri, M. and Fadley, F. (2004) Long Term Outcome (Up to 15 Years) of Balloon Angioplasty of Discrete Native Coarctaion of Aorta in Adolescents and Adults. Journal of the American College of Cardiology, 4, 10621067. http://dx.doi.org/10.1016/j.jacc.2003.10.040

[35] Hijazi, Z.M., Fahey, J.T., Kleinman, C.S., William, E.H., et al. (1991) Balloon Angioplasty for Recurrent Coarctation of Aorta Immediate and Long-Term Results. Circulation, 84, 1150-1156. http://dx.doi.org/10.1161/01.CIR.84.3.1150

[36] Article No. euhj. 1998.1448. http://www.idealibrary.com

[37] Calderon, M.J., Cerdeira, Z.C., Velazco, L.M., Perez, A.T., et al. (2002) Balloon Angioplasty in Aortic Coarctation: A Multicentric Study in Mexico. Archivos de Cardiologia de Mexico, 72, 20-28.

[38] Shaddy, R.E., Boucek, M.M., Sturtevant, J.E., Ruttenberg, H.D., Jaffe, R.B., Tani, L.Y., Judd, V.E., Veasy, L.G., McGough, E.C. and Orsmond, G.S. (1993) Comparison of Angioplasty and Surgery for Unoperated Coarctation of the Aorta. Circulation, 87, 793-799. http://dx.doi.org/10.1161/01.CIR.87.3.793

[39] Fawzy, M.E., Sivanandam, V., Pieters, F., Stefadouros, M.A., Galal, O., Dunn, B., Kinsara, A., Khan, B., Al-Halees, Z., et al. (1999) Long-Term Effects of Balloon Angioplasty on Systemic Hypertension in Adolescent and Adult Patients with Coarctation of the Aorta. European Heart Journal, 20, 827-832. http://dx.doi.org/10.1053/euhj.1998.1448

[40] Scott, E.F., Nihill, M.R., Martin, P., et al. (1995) Balloon Angioplasty for Native Coarctation 
of Aorta: Midterm Follow-Up and Prognostic Factors. Journal of the American College of Cardiology, 25, 730-734. http://dx.doi.org/10.1016/0735-1097(94)00437-U

[41] Tynan, M., Finley, J.P., Fontes, V., Hess, J. and Kan, J. (1990) Balloon Angioplasty for the Treatment of Native Coarctation: Results of Valvuloplasty and Angioplasty of Congenital Anomalies Registry. The American Journal of Cardiology, 65, 790-792. http://dx.doi.org/10.1016/0002-9149(90)91389-n

[42] Rao, P.S., Thapar, M.K., Kutayli, F. and Carey, P. (1989) Causes of Recoarctation after Balloon Angioplasty of Unoperated Aortic Coarctations. Journal of the American College of Cardiology, 13, 109-115. http://dx.doi.org/10.1016/0735-1097(89)90557-3

[43] Rao, P.S., Najjar, H.N., Mardini, M.K., Solymar, L., Thapar, M.K., et al. (1988) Balloon Angioplasty for Coarctation of the Aorta: Immediate and Long-Term Results. American Heart Journal, 115, 657-665. http://dx.doi.org/10.1016/0002-8703(88)90817-4

[44] Baron, M.G. (1971) Obstruction of the Aortic Knob in Coarctation of Aorta. Circulation, 43, 311-316. http://dx.doi.org/10.1161/01.CIR.43.2.311

Submit or recommend next manuscript to SCIRP and we will provide best service for you:

Accepting pre-submission inquiries through Email, Facebook, LinkedIn, Twitter, etc. A wide selection of journals (inclusive of 9 subjects, more than 200 journals)

Providing 24-hour high-quality service

User-friendly online submission system

Fair and swift peer-review system

Efficient typesetting and proofreading procedure

Display of the result of downloads and visits, as well as the number of cited articles Maximum dissemination of your research work

Submit your manuscript at: http://papersubmission.scirp.org/ 